\title{
First record of the genus Physaloptera sp. (Nemata: Physalopteridae) in scats from coyote, Canis latrans in Chihuahua, México
}

\author{
Fernando Álvarez-Córdova ${ }^{1 *}$, Jesús A. Fernández ${ }^{1}$, Elizabeth A. Martínez-Salazar² and Rogelio Rosas-Valdez ${ }^{2}$ \\ 'Departamento de Recursos Naturales, Facultad de Zootecnia y Ecología, Universidad Autónoma de Chihuahua. Periférico Francisco \\ R. Almada Km. 1, CP. 31453, Chihuahua. Chihuahua, México. Email: biofer.alva@gmail.com (FAC), jaff1789@gmail.com (JAF). \\ ${ }^{2}$ Laboratorio de Colecciones Biológicas y Sistemática Molecular, Unidad Académica de Ciencias Biológicas, Universidad Autónoma \\ de Zacatecas. Campus II, Av. Preparatorio s/n Col. Agronómica, CP. 98066, Zacatecas. Zacatecas, México. Email: rogrosas.uaz@ \\ gmail.com (RRV), eamsuaz@gmail.com (EAMS). \\ *Corresponding author
}

The knowledge of the helminth parasites of Canis latrans from México is scarce. This study 23 scats of C. latrans were collected and examined to identify alimentary items between April and September of 2018, at the rancho experimental Teseachi of the Universidad Autónoma de Chihuahua, in Namiquipa, Chihuahua, México. Three nematode specimens of Physaloptera sp. were found and identified by morphology. This endoparasite is reported for the first time in scats of $C$. latrans for the state of Chihuahua.

El conocimiento de los helmintos parásitos de Canis latrans de México es escaso. Este estudio 23 excretas de C. latrans fueron recolectadas y examinadas para identificar atributos alimenticios entre Abril y Septiembre del 2018 en el rancho experimental Teseachi de la Universidad Autónoma de Chihuahua, en Namiquipa, Chihuahua, México. Tres especímenes de nemátodos de Physaloptera sp. fueron encontrados e identificados por su morfología. Se reporta por primera vez este género de endoparásito en excretas de C. latrans para el estado de Chihuahua.

Key words: canidae; carnivora; endoparasite; mammals; nematoda; parasitism.

(c) 2019 Asociación Mexicana de Mastozoología, www.mastozoologiamexicana.org

\section{Introduction}

Canis latrans is a predator with a high degree of adaptation to different ecosystems, from desert to tropical and temperate environments (Bekoff and Gese 2003). Its distribution extends from Costa Rica to northern Alaska (Bekoff 1977). Their reproductive success, the ability to disperse, and their supreme success at adapting to different environments and resources has allowed coyotes to expand both their range and their diet which is now basically omnivorous. These characteristics have made coyotes one of the most abundant and widely distributed carnivores on the American continent (Bekoff 1977; Hall 1981; Vaughan and Rodríguez 1986).

The omnivore diet of $C$. latrans promotes infections by different endoparasite species such as Platyhelminthes and nematodes in the Nearctic Realm: Ancylostoma spp., Capillaria spp., Dirofilaria spp., Physaloptera sp., Strongyloides sp., Toxascaris spp., Trichinella spp., among others nematode parasites reported (Ramalingam and Carbyn 1978; Hernández and Laundré 2014; Luna-Estrada et al. 2017). Curiously, up to the present time, there few records of parasites of Canis latrans in México, one record the nematode Strongyloides sp. parasitizing C. latrans from the Zoológico "Manuel Álvarez del Toro", in Chiapas, México (in García-Prieto et al. 2012); and one records the nematode Dirofilaria immitis near Queretaro City, México (Hernández and Pineda 2012).

Eight records of parasites have been reported from the municipality of Tepehuanes, Durango; five nematodes (Ancylostoma caninum, Physaloptera sp., Spirocerca lupi, Spi- rura sp., and Didelphonema longispiculata), one trematode (Alaria sp.) and one cestode (Taenia pisiformis; Luna-Estrada et al. 2017). To the best of our knowledge, there is no information on the endoparasites of $C$. latrans from the state of Chihuahua. The aim of this paper was to present the first record of Physaloptera sp. obtained from scats of $C$. latrans in the state of Chihuahua, México.

\section{Materials and Methods}

Study area. The main goal of the rancho experimental Teseachi is teaching, research and transfer of technology in animal science and natural resources (Espinoza and Quintana 2003). It is located among the municipalities of Namiquipa, Bachiniva and Guerrero in Chihuahua, México ( $28^{\circ} 53^{\prime} 44^{\prime \prime} \mathrm{N}$, $-107^{\circ} 27^{\prime} 22^{\prime \prime} \mathrm{W}, 2,250$ masl). This site has an approximate area of 12,300 hectares, the landscape is shaped by hills and high mountain ranges displaying a mixture of open medium grassland, arboreal pasture grasses, oak chaparral, pine-oak forest, and temperate forest. Comisión Técnico Consultiva de Coeficientes de Agostaderos (COTECOCA 1978).

Data collection and identification of parasites. Linear transects of five kilometers were revised in search of scats. A total of 23 scats of $C$. latrans were collected from April to September of 2018, the scats were identified as belonging to C. latrans according to the characteristics detailed by Aranda (2012). Each scat collected was georeferenced through a Global Positioning System (GPS), and measurements (width and length) were taken with a measuring tape, and they were subsequently stored individually in 
airtight bags. Once in the laboratory at Facultad de Zootecnia y Ecología, Universidad Autónoma de Chihuahua, they were cleaned using conventional means (Arnaud 1993). The nematodes were collected and stored in glass vials with $70 \%$ ethanol to preserve morphological traits for further identification.

The identification of the nematodes was conducted in the Laboratorio de Colecciones Biológicas y Sistemática Molecular (LCBySM), Unidad Académica de Ciencias Biológicas (UACB), Universidad Autónoma de Zacatecas (UAZ), Zacatecas, Zacatecas, México, using conventional morphological techniques (Lamothe-Argumedo 1997) and identified using specialized literature (Chabaud 1975). Voucher specimen was deposited in the reference collection in the laboratory previously mentioned: Colección de Invertebrados no Artrópodos (CINZ08).

\section{Results}

From the 23 scats examined, only one was positive for worms parasites (prevalence of $4.3 \%$ ) with three specimens; two females were identified and the other was in high degree of decomposition. Nematodes were identified through the use of morphological characters, and they clearly belong to genus Physaloptera sp. (Nemata: Physalopteridae). The two specimens obtained were measured with an average total length of $24 \mathrm{~mm}$. In the optical microscope different structures were observed that allowed the identification at genus level, such as the anal opening, the size and structure of the embryonated eggs [42.11 to 55.47 (50.61) $\pm 2.95 \mu \mathrm{m}$ long $\times 30.00$ to 36.70 (32.40) $\pm 1.75 \mu \mathrm{m}$ width, $n=20$ ], and cephalic features, such as two large, simple, triangle lateral lips, two pairs of frontal papillae, internal teeth (three in each lip) and presence of a well developed stoma (Figure 1 to 3). Because there were no males collected, it was not possible to identify these nematodes to the species level (Ramalingam and Carbyn 1978; Ortlepp 1922).

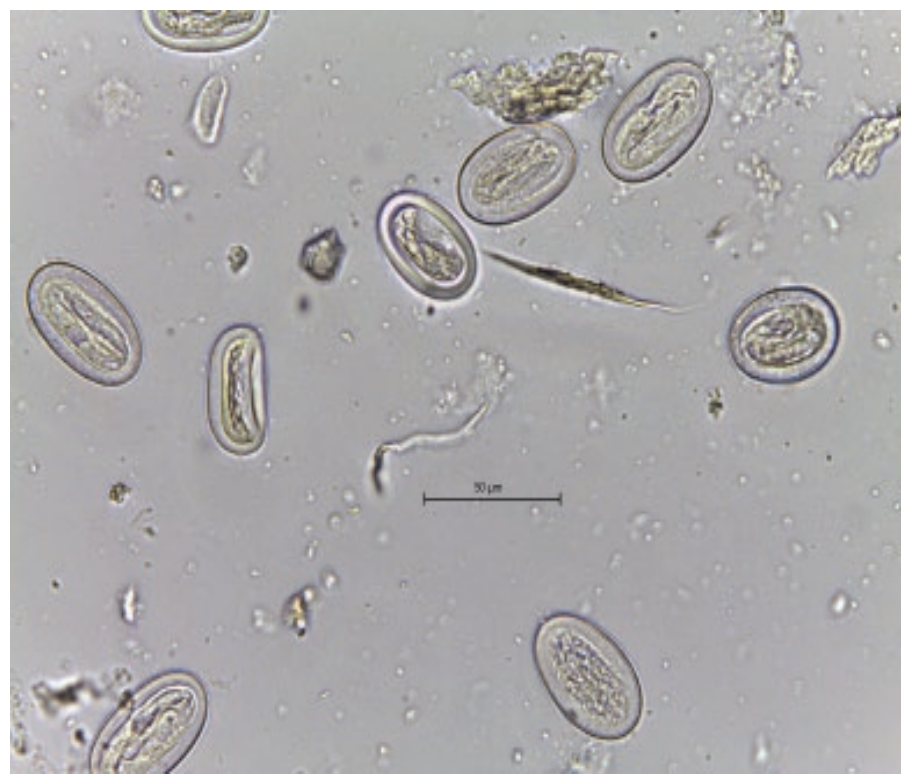

Figure 1. Embryonated eggs of Physaloptera sp. Scale bar $=50 \mu \mathrm{m}$

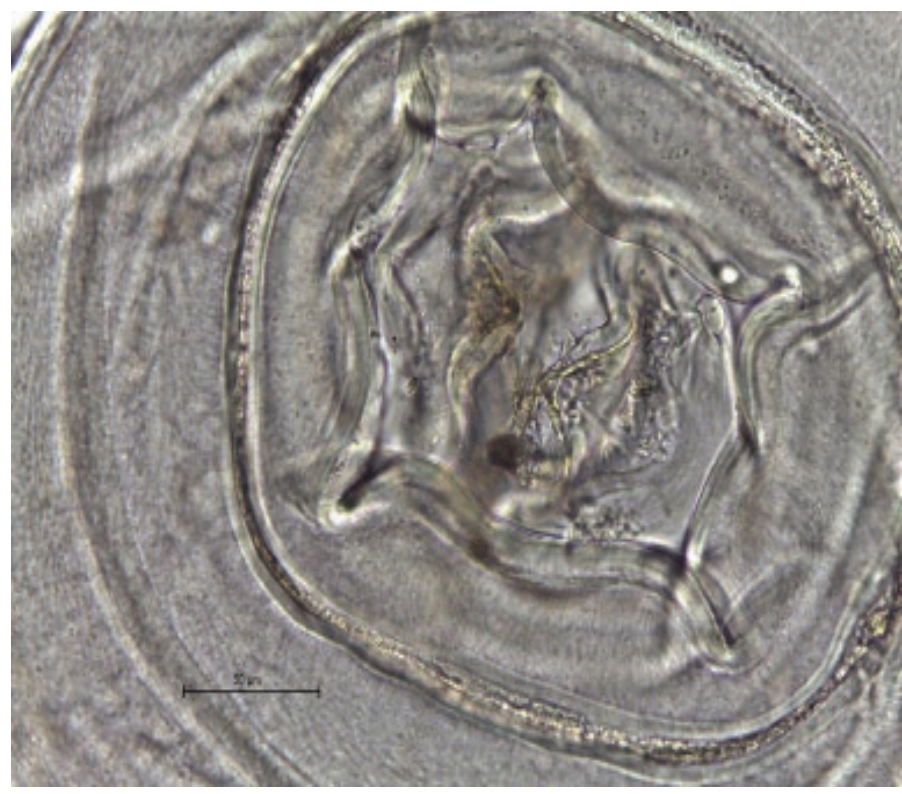

Figure 2. Cephalic end, apical view. Scale bar $=50 \mu \mathrm{m}$.

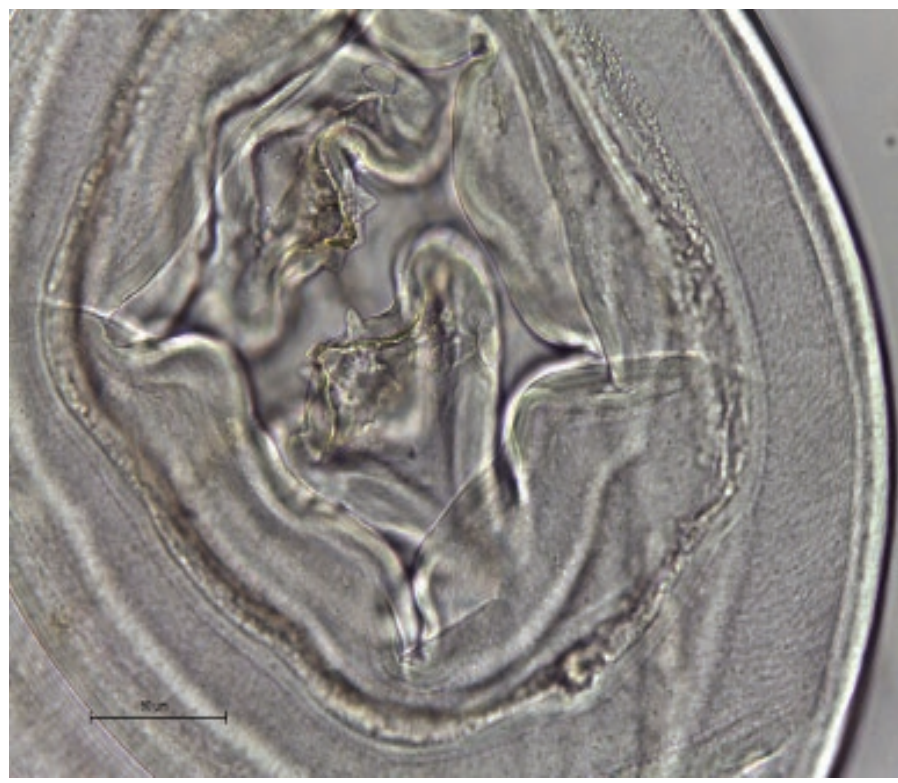

Figure 3. Internal teeth (three in each lip) and buccal cavity. Scale bar $=50 \mu \mathrm{m}$.

\section{Discussion}

For the Mexican Republic there are few records documenting infection of nematodes in C. latrans through gastrointestinal dissections, however none with scats review (García-Prieto et al. 2012; Hernández and Pineda 2012; LunaEstrada et al. 2017). To our knowledge, for the state of Chihuahua there was no record of Physaloptera sp. in C. latrans. The presence of Physaloptera sp. in Chihuahua agrees with Luna-Estrada et al. (2017), they reported the presence of this nematode in C. latrans in northern México, in Tepehuanes Durango (at $425 \mathrm{~km}$ lineal distance approximately). Nematode species of the genus Physaloptera (Nematoda: Physalopteridae) are parasites of mammals, birds and reptiles (Chabaud 1975).

The life cycle of Physaloptera spp. is indirect, the coyotes are considered the definitive hosts of the Physaloptera rara from North America (Ameel 1955), the infections is 
through oral ingestion of the intermediate hosts (e. g., beetles, crickets, cockroaches, earwigs and grasshoppers) or ingestion of paratenic hosts, such as mice that are infected with encysted juvenile or larval Physaloptera sp. (Petri 1950; Olsen 1980). The presence of Physaloptera sp. in coyote scats agrees with the feeding habits of this canid, because this nematode is parasite of intermediate hosts like lagomorphs and rodents. They are common prey of $C$. latrans, where the parasites complete its life cycle (Luna-Estrada et al. 2017).

Parasites are an important part of the natural biota of free-living organisms, playing a role as bioindicators of ecosystem health (Marcogliese 2005), despite this, there is a lack of information on Mexican mammal parasites, so it is necessary to increase the study of helminth fauna in the Mexican Republic. This is the first report of Physalopera sp. in scats of $C$. latrans in Chihuahua, Chihuahua, México.

\section{Acknowledgements}

We want to thank the Conabio (Comisión Nacional para el Conocimiento y Uso de la Biodiversidad) and Conanp (Comisión Nacional de Áreas Naturales Protegidas) for financial support through project PJ006; FZyE-UACH for kindly allowing us access to the study location. To A. Camargo., V. Ramos, and J. Sandoval, for her help doing field work. FAC thanks the Consejo Nacional de Ciencia y Tecnología for the support of the master's scholarship.

\section{Literature cited}

AmEel, D.J. 1955. Parasites of the Coyote in Kansas. Transactions of the Kansas Academy of Science 58:208-210.

Arnaud, G. 1993. Alimentación del coyote (Canis latrans) en Baja California Sur, México. Pp. 205-240 in Avances en el Estudio de los Mamíferos de México (Medellín, R. A., and G. Ceballos, eds.). Publicaciones Especiales Vol. 1, Asociación Mexicana de Mastozoología, A. C. Distrito Federal, México.

Aranda, M. S. 2012. Manual para el rastreo de mamíferos silvestres de México. Comisión Nacional para el Conocimiento y Uso de la Biodiversidad (Conabio). Distrito Federal, México. BeKoff, M., AND E. M. Gese. 2003. Coyote (Canis latrans). USDA National Wildlife Research Center-Staff Publications. Pp. 467481 in Wild Mammals of North America:Biology, Management, and Conservation (Feldhamer, G. A., B. C. Thompson, and J. A. Chapman, eds.). $2^{\text {nd }}$ edition. Johns Hopkins University Press. Baltimore, U. S. A.

BeKoff, M. 1977. Canis latrans. Mammalian species 79:1-9.

Chabaud, A. G. 1975. ClH keys to the nematode parasites of vertebrates. 3. Keys to genera of the order Spirurida. Ascaridoidea. Part I. Camallanoidea, Dracunculoidea, Gnathostomatoidea, Physalopteroidea, Rictularoidea and Thelazioidea (Anderson, R. C., A. G. Chabaud, and S. Willmott, eds.). Commonwealth Agricultural Bureaux. Farnham Royal, U.K.

Comisión Técnico Consultiva para la Determinación Regional de los Coeficientes de Agostadero (COTECOCA). 1978. Secretaria de Agricultura y Recursos Hidráulico. Subsecretaria de ganadería. SARH. Chihuahua, México.
EspinOZA, J. R., AND R. M. QuintanA. 2003. Área de conservación y manejo sustentable de los recursos naturales rancho Teseachi en la UACH para un modelo educativo y responsabilidad social. Centro de Estudios e Investigación para el Desarrollo Docente. Chihuahua, México.

García-Prieto, L., J. Falcón-Ordaz, and C. Guzmán-Cornejo. 2012. Helminth parasites of wild Mexican mammals. List of species, host and geographical distribution. Zootaxa 3290:1-92.

HALL, E. R. 1981. The mammals of North America. Vol. Il. 2a. ed. Wiley-Intersciencie. New York, U. S. A.

Hernández, C. N., and L. R. F. Pineda. 2012. Primer registro de Dirofilaria immitis (Spirurida: Onchocercidae) en coyotes de México. Acta Zoológica Mexicana (n. s.) 28:659-662.

Hernández, L., And J. W. Laundré. 2014. Coyotes en México. Pp. 271-293 in Ecología y Manejo de fauna silvestre en México (Valdéz, R., and J. A. Ortega, eds.). Colegio de posgraduados. Guadalajara, México.

LAmOthe-ARgumedo, R. 1997. Manual de técnicas para preparar y estudiar los parásitos de animales silvestres. AGT Editor. Ciudad de México, México.

Luna-Estrada, M., M. A. Mosqueda-Cabrera, and J. Servín. 2017. Nuevos registros de helmintos en coyote Canis latrans impavidus (Carnivora: Canidae) en México. Revista Mexicana de Biodiversidad 88:250-252.

MARCogliese, D. J. 2005. Parasites of the superorganism: are they indicators of ecosystem health? International Journal for Parasitology 35:705-716.

OLSEN, J. L. 1980. Life history of Physaloptera rara Hall and Wigdor, 1918 (Nematoda: Physalopteroidea) of canids and felids in definitive, intermediate, and paratenic hosts. Revista Ibérica de Parasitología 40:489-525.

OrtLepp, R. J. 1922. The nematode genus Physaloptera Rud. Proceedings of the Zoological. Society of London 92:999-1107.

PEtRl, L. H. 1950. Life cycle of Physaloptera rara Hall and Wigdor, 1918 (Nematoda: Spiruroidea) with the cockroach, Blatellagermanica serving as intermediate host. Transactions of the Kansas Academy of Science 53:331-337.

Ramalingam, S., AND L. N. Carbyn. 1978. Helminths in coyotes (Canis latrans Say.), wolves (Canis lupus L.), and red foxes (Vulpes vulpes L.) of southwestern Manitoba. Canadian Journal of Zoology 56:2614-2617.

Vaughan, C., AND M. Rodriguez. 1986. Comparación de los hábitos alimentarios del coyote (Canis latrans) en dos localidades de Costa Rica. Vida Silvestre Neotropical 1:6-11.

Associated editor: Sergio Ticul Álvarez-Castañeda. Submitted: April 1, 2019; Reviewed: April 4, 2019; Accepted:April 24, 2019; Published on line: April 28, 2019. 
186 THERYA Vol. 10 (2): 183-185 